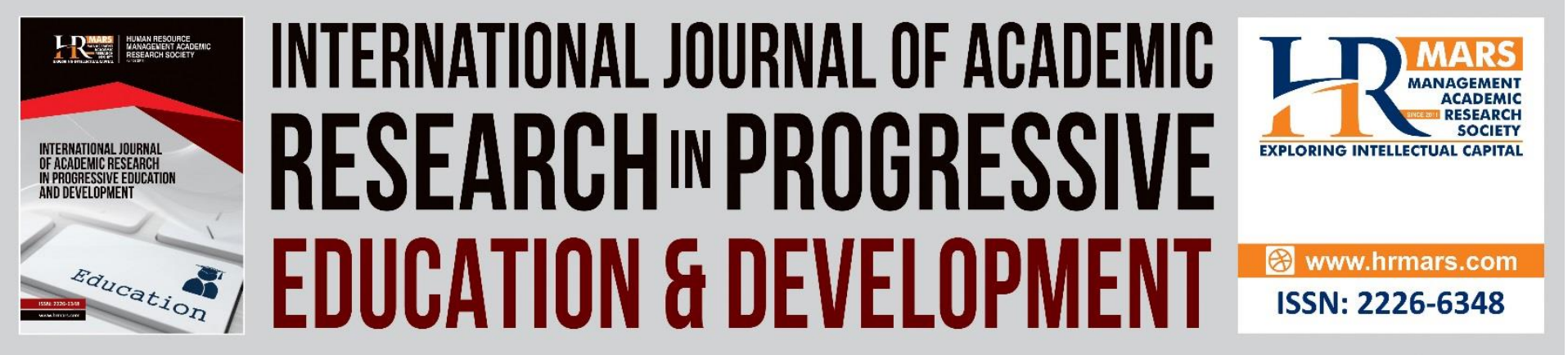

\title{
Physical Fitness Performance Comparison based on Body Mass Index between Individual Sports and Team Sports Athletes
}

Noor Aishah Kamarudin, Mohamad Razali Abdullah, Rabiu Muazu Musa, Vijayamurugan Eswaramoorthi, Ahmad Bisyri Husin Musawi Maliki, Aina Munirah Ab Rasid, Ahmad Nadzmi

To Link this Article: http://dx.doi.org/10.6007/IJARPED/v11-i1/12057

DOI:10.6007/IJARPED/v11-i1/12057

Received: 20 November 2021, Revised: 23 December 2021, Accepted: 07 January 2022

Published Online: 25 January 2022

In-Text Citation: (Kamarudin et al., 2022)

To Cite this Article: Kamarudin, N. A., Abdullah, M. R., Musa, R. M., Eswaramoorthi, V., Maliki, A. B. H. M., Rasid, A. M. A., \& Nadzmi, A. (2022). Physical Fitness Performance Comparison based on Body Mass Index between Individual Sports and Team Sports Athletes. International Journal of Academic Research in Progressive Education and Development, 11(1), 342-359.

Copyright: (C) 2022 The Author(s)

Published by Human Resource Management Academic Research Society (www.hrmars.com)

This article is published under the Creative Commons Attribution (CC BY 4.0) license. Anyone may reproduce, distribute, translate and create derivative works of this article (for both commercial and non-commercial purposes), subject to full attribution to the original publication and authors. The full terms of this license may be seen at: http://creativecommons.org/licences/by/4.0/legalcode

Vol. 11(1) 2022, Pg. 342 - 359

http://hrmars.com/index.php/pages/detail/IJARPED

JOURNAL HOMEPAGE

Full Terms \& Conditions of access and use can be found at http://hrmars.com/index.php/pages/detail/publication-ethics 


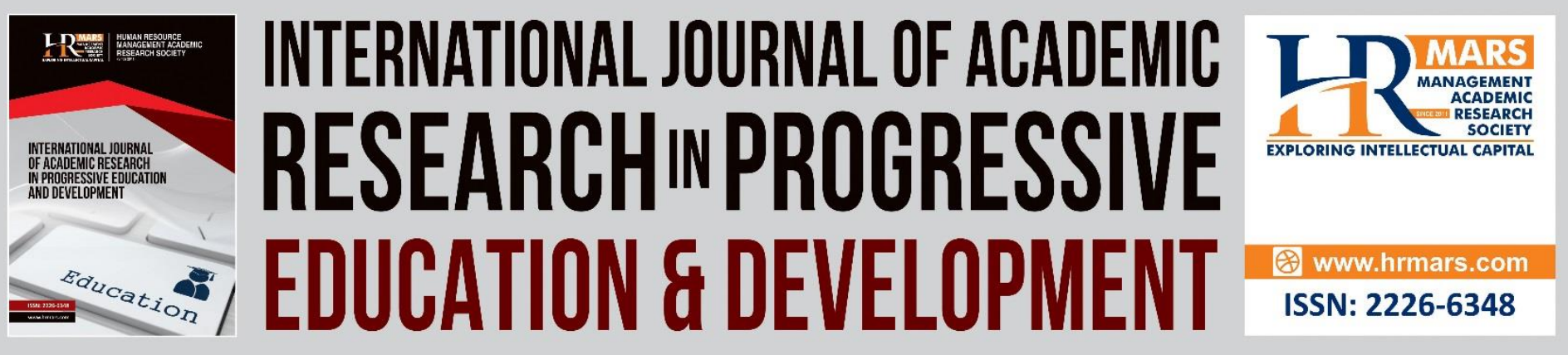

\title{
Physical Fitness Performance Comparison based on Body Mass Index between Individual Sports and Team Sports Athletes
}

Noor Aishah Kamarudin', Mohamad Razali Abdullah², Rabiu Muazu Musa ${ }^{3}$, Vijayamurugan Eswaramoorthi ${ }^{4}$, Ahmad Bisyri Husin Musawi Maliki ${ }^{5}$, Aina Munirah Ab Rasid ${ }^{6}$, Ahmad Nadzmi ${ }^{7}$

${ }^{1,4}$ Faculty of Health Sciences, Universiti Sultan Zainal Abidin. 21300 Kuala Nerus, Terengganu, Malaysia, ${ }^{2}$ East Coast Environmental Research Institute' Universiti Sultan Zainal Abidin. 21300 Kuala Nerus, Terengganu, Malaysia, ${ }^{3}$ Centre for Fundamental and Liberal Education, Universiti Malaysia Terengganu. 21030 Kuala Nerus, Terengganu, Malaysia,

${ }^{5,7}$ Academy of Defence Fitness, National Defence University of Malaysia, Kem Sungai Besi, 57000 Kuala Lumpur, Malaysia, ${ }^{6}$ Centre for Fundamental and Continuing Education,

Universiti Malaysia Terengganu. 21030 Kuala Nerus, Terengganu, Malaysia Co-author: rabiumuazu86@gmail.com

\begin{abstract}
Individual sports and team sports have their own characteristic and require specific fitness level and optimum anthropometry component such as body composition to be fit in the sports. The purpose of this study to differentiate the physical fitness performance based on $\mathrm{BMI}$ of individual sport and team sport athletes. A total of 147 Terengganu junior male athletes aged 13 to 21 who are participate in the Malaysian Games participated different types of individual and team sports. BMI was distributed according to World Health Organization (WHO) standard as $<18.5 \mathrm{~kg} / \mathrm{m} 2$ under-weight, $18.5-24.9 \mathrm{~kg} / \mathrm{m} 2$ normal weight, $25-29.9 \mathrm{~kg} / \mathrm{m} 2$ over weight and $>30 \mathrm{~kg} / \mathrm{m} 2$ obesity. Tests were used in this study is Sit and Reach (flexibility), Sit Up (upper muscle endurance), Maximum Push Up (upper muscular strength), Handgrip (handgrip strength), Predicted $\mathrm{VO}_{2} \max$ (cardiovascular), Standing Medicine ball Throw (upper body strength), 20 meter Sprint Test (speed), Vertical Jump (leg power), Stork Stand (balance), Standing Broad Jump (leg explosive power), and T test (agility). Result showing all test except sit up test and stork stand test have a significant difference between type of sport and the athlete's respectively BMI class. For summary, each type of sports with representative BMI class have their own specialities in physical fitness performance. More studies are needed to understand the complexity of this topic especially focusing on the recognize the specificity requirement of physical fitness on different type of sport and BMI class.
\end{abstract}

Keyword: Body Mass Index, Physical Fitness Performance, Individual Sports, Team Sports 


\section{Introduction}

Body composition is recognised as determinants of sports performance and health (Ackland et al., 2012; Campa et al., 2021). Indeed, in many sports, an athlete can gain an advantage by changing their body mass or body composition features. Gymnastics, for example, has both an aesthetic and a gravitational component; hence, anthropometric features may influence a gymnast's competition success (Bacciotti et al., 2017). Athletes must also remain within a specified body mass range in various sports since many sport are weightclassified (Franchini et al., 2012). As a result, athletes carefully customize their training and eating habits to the demands of their particular sport (Sundgot-Borgen \& Torstveit, 2010). In this context, monitoring body composition has become crucial, and assessing it appropriately allows for an accurate evaluation

Body composition can play a significant part in establishing personalised training programmes for athletes in order for them to attain their goals and obtain optimal performance and talent recognition sensibility for athletic achievement to recognise talent (Faizatul et al., 2021; Mujika et al., 2018). The phenomenon known as the "sports morphological optimization" explains that the body composition of a particular athlete is determined by the sports they participate in, and variances in body fat and muscle percentage in athletes are produced by body composition adjustments to a variety of individual sports (M. Lozovina et al., 2012; V. Lozovina \& Lozovina, 2008, 2008).

Understanding the ideal lean and fat mass for the upper and lower body, as well as total body mass, is essential for the success of any individual or team sport's training and dietary plans. Team sports need a group of individuals that will be organized into opposing teams which compete to win. So, there will be many tactical and strategies available that require aggressiveness, sudden pace-change, counter attacks and defensives. Thus, in order to execute the strategies, optimum fitness performance needed to execute the tactical and to cover up the strength and weakness available on each athlete. The same is true for individual sports, in which the participants are solely responsible for their own performance. As for the coaches, the small redundant like BMI changes are need an extra focus for coach because there will be no one to cover up the weakness of the athlete except the athlete itself in the arena. Thus, if there is a change in BMI, it will also affect the athlete's performance. For example, in kickboxing sport study from Rydzik \& Ambroży, (2021), stating that during Covid 19 outbreak, the kickboxer's training were suspended due to the self-isolation order and because of that no trainings were ongoing during that time and this causing their performance dropped.

The time restrictions of sport-specific competition preparation, a lack of strengthtraining possibilities, and an increased metabolic effort might all contribute to visible body composition changes. (Roelofs et al., 2017). While most research has concentrated on changes that occur during the off- and pre-season, to the best of knowledge, no study has looked at the differences in body composition that may occur and how these changes may affect sports performance (Owen et al., 2018). If an athlete's BMI changes, especially if it increases, the athlete's maximal performance potential is limited, as high BMI is associated with low performance. (Hardy et al., 2013, Nikolaidis \& Ingebrigtsen, 2013; Nikolaidis et al., 2019). Restriction of maximum potential also will lead to the discrimination of athlete selection and become biased due to the performance flop (Abd Hadi et al., 2021). The purpose 
DEVELOPMENT

Vol. 11, No. 1, 2022, E-ISSN: 2226-6348 @ 2022 HRMARS

of this study to differentiate the physical fitness performance based on BMI of individual sport and team sport athletes.

\section{Methodology \\ Participants}

The study's subjects are 147 Terengganu junior male athletes aged 13 to 21 who are participate in the Malaysian Games. There have been eight different forms of sports, with five different types of individual sports and three different types of team sports. Throughout the research period, the athlete's overall physical fitness test was taken and assessed. All of the athletes signed consent papers, which have been collected in writing. The Terengganu Sports Institute Council (MSNT) Board examined and approved all of the study's protocols, procedure, and equipment, with the approval number MSN.TR.15 (22).

\section{Body Mass Index}

BMI, formerly called the Quetelet index, is a metric for determining an adult's nutritional status. is calculated by dividing a person's weight in kilogrammes by the square of their height in metres. $(\mathrm{kg} / \mathrm{m} 2)$. The level of BMI was distributed according to World Health Organization (WHO) standard as $<18.5 \mathrm{~kg} / \mathrm{m} 2$ under-weight, $18.5-24.9 \mathrm{~kg} / \mathrm{m} 2$ normal weight, $25-29.9 \mathrm{~kg} / \mathrm{m} 2$ over weight and $>30 \mathrm{~kg} / \mathrm{m} 2$ obesity (Chandra et al., 2020). In this study, athlete's BMI that involved were normal class, underweight class and overweight class.

\section{Health Related Fitness Component (HRFC)}

Standard physical fitness evaluations were used in conjunction with routine physical fitness indicators such as flexibility, upper muscle endurance, upper muscle endurance, grip strength, cardiovascular endurance, and upper body strength. Before the testing periods, the participants conducted a warm-up that included a 5 to 10 minute jog and a series of stretches.

\section{Sit and Reach test (Flexibility)}

When performing sit and reach, athletes must sit on the ground with straight legs, knees on the ground, and feet facing the flat surface of the sit and reach box.(Ryan et al., 2014). With little pressure, the conductor keeps the athlete's sides of the knees straight against the floor. With their hands on top of each other, gently pushing the measuring slide as far as possible over the measurement line, the athletes carefully pushed forward their fingertips. While recording the distance, the conductor must maintain the reach for at least two seconds. The conductor must ensure that the athlete's' fingers and legs are in a stable straight position with no jerky movements. The test results must be taken in $0.5 \mathrm{~cm}$ increments.

\section{Sit up (Upper Muscle Endurance)}

The sit-up test is used to assess upper-body endurance. Athlete did a sit-up test with their knees bent at 90 degrees and their feet flat on the ground, as well as a push-up test with their legs extended (Abdullah et al., 2016). The number of completed sit-ups and push-ups in 1-minute was recorded. 
DEVELOPMENT

Vol. 11, No. 1, 2022, E-ISSN: 2226-6348 @ 2022 HRMARS

\section{Push up (Upper Muscular Strength)}

In this test, the upper muscular strength was assessed. The athletes sat on the floor in a prone posture with their hands just below their shoulders, stretched legs, and tucked toes in order to make contact with the floor (push up position). The athletes then extend their arms to their full length before lowering their bodies to the floor and lowering their chests. At this stage, the line from head to toe should be straight.(Abdullah et al., 2017). Only the arms and shoulders were used to carry out these manoeuvres. The number of push-ups performed while keeping proper technique until the participants were fatigued decided the score.

\section{Handgrip Test (Grip Strength)}

The maximal isometric strength of the athletes' hand and forearm muscles was measured using the hand grip (HG). (Taha et al., 2018). A hand grip dynamometer was used to conduct this test, and the athletes were asked to grab the dynamometer in their hand to be tested, with their arm at right angles and their elbow by their side of the body. The dynamometer's knob is adjusted according to the athlete's size. The first metacarpal (palm heel) served as the basis of the hand grasp, with the handle resting in the midst of four fingers. When the participants were ready, they were allowed to squeeze the dynamometer at maximum isometric effort for roughly 5 seconds. Other than that, there was no room for movement. The researchers urged the athletes to put up their best effort. The hands were switched back and forth.

\section{Predicted $\mathrm{VO}_{2} \max$ (Cardiovascular Endurance)}

The participant's predicted maximal oxygen consumption was determined using a multistage 20-meter shuttle run test (Suhaimi et al., 2021). The athlete ran as long as they could till they couldn't keep up with the tempo of the speeding rhythm and shuttle run test tape's speed any longer. All test results were expressed as an estimated VO2max, which was calculated by looking at the final level and shuttle number at the time the person voluntarily quit the test. Although the participants' desires and objectives may impact their results, it is still a viable test for predicting projected maximal oxygen uptake and may be conducted with a large number of participants at a low cost and in a short amount of time.

\section{Standing Medicine Ball Throw (Upper Body Strength)}

The overhead throw for distance is a strength test that entails throwing the ball forward from above the head. Medicine ball throw tests are used to evaluate upper-body strength. Starting with the breadth of the feet, the heels on the measuring line zero, and maintaining the medicine ball straight out at the foot, the standing medicine ball was produced. (Stockbrugger \& Haennel, 2001). Participants were given at least 5 to 6 practise attempts to ensure a consistent score and familiarity with the technique necessary, which included optimising the angle of release and maximum power output. After completing the trial, participants were given the opportunity to take the exam for a real-time scoring session. Three timed trials in which they threw a medicine ball as far as they could. The distance of each throw was measured (meters).

\section{Skill Related Fitness Component (SRFC)}

The 20-meter speed, leg power, balance, leg explosive power, and agility are all skillrelated fitness component tests. 
DEVELOPMENT

Vol. 11, No. 1, 2022, E-ISSN: 2226-6348 @ 2022 HRMARS

\section{0-meter Sprint Test (Speed)}

The 20-meter sprint (20MS) was performed according to the technique in the EUROFIT test battery (Nadzmi et al., 2021). Before beginning the test, athletes were advised to remain in a standing stance with the aim of sprinting, such as by positioning one dominant leg near the starting point to function as a momentum starter. The tester will blow a whistle, and the athletes will begin running. The time begins to be recorded when the athletes begin running from the starting line and ends when the runner crosses the finish line. Intermittently, each participant receives two trials. Up to two decimal point $(0.01)$ seconds of reading will be captured.

\section{Vertical Jump (Leg Power)}

Leg power is measured by a vertical jump. The color-coded plastic vanes' height was adjusted to correspond to the athletes' standing height. The athlete flexed their ankles, knees, and hips, swung their arms upward, and used their dominant hand's fingers to tap the highest possible vane (Bisyri et al., 2018). For statistical analysis, the best of the three trials was chosen.

\section{Stork Stand (Balance)}

Body balance is measured using the standing stork test. A stopwatch was used to time the standing stork (SS) test. The athletes took off their shoes, put their hands on their hips, rose their heels to balance on the ball of their foot, and positioned their non-supporting foot on the inner part of the supporting leg (Schorderet et al., 2021). The test is terminated if the athletes are unable to maintain the exact position.

\section{Standing Broad Jump (Leg Explosive Power)}

Leg explosive power was measured using the standing broad jump test. Participants in a standing broad jump (SBJ) must stand behind a line erected in the area. After a two-foot take-off leap, the competitors will land with their arms swinging back and their knees bent rhythmically at around 90 degrees forward. The athlete must land on both feet and jump as high as they can without falling backward. The test will be rejected if the athletes does not follow the instructions (Nadzmi et al., 2021). Only three trials were allowed at the time, with the highest score being recorded.

\section{T test (Agility)}

To determine agility, the 'T-test agility test' was performed. The procedure was followed exactly as it was written. The points are spaced 10-5-5 metres apart on a T-shaped line painted on the ground. Athletes race back over the $5 \mathrm{~m}$ markers from the $10 \mathrm{~m}$ marker near the line, past the $5 \mathrm{~m}$ markers, turn on the line, and sprint back over the $10 \mathrm{~m}$ markers. From the time the runner initially runs past the $5 \mathrm{~m}$ back to $10 \mathrm{~m}$ markers until they halt, the time is recorded using an infrared speed trap (Brower Timing system). Each athlete tried their maximum two times, with the quickest time being recorded for analysis. It was urged to the participant not to go too much over the line since it would extend their time.

\section{Statistical Analysis}

\section{Multivariate Analysis of Variance (MANOVA)}

MANOVA is a member of the General Linear Model-a family of statistical procedures that are often used to determine the strength of a relationship between two variables 
DEVELOPMENT

Vol. 11, No. 1, 2022, E-ISSN: 2226-6348 @ 2022 HRMARS

(Zientek \& Thompson, 2009). MANOVA, specifically, is an analysis of variance (ANOVA) that has two or more dependent variables (Gipit Charles et al., 2017). In this study, MANOVA will be used to identify the pros and cons of physical performance for each type of sport, individual sport athlete and team sport athlete based on their BMI by using Pairwise Comparison method. This method will show the mean difference between the mean of the analysis (I-J).

\section{Result and Findings}

Table 1 below shows the summary of MANOVA analysis, analysis have identified the optimum physical fitness performance component between individual sports and team sports based on their BMI. From the result, showing that in HRFC tests, Sit and Reach test (Pr $>f=$ 0.000), Push Up (Pr $>f=0.000)$, Handgrip ( $\operatorname{Pr}>f=0.000)$, Predicted VO2max ( $\operatorname{Pr}>f=0.000)$, Standing Medicine Ball Throw $(\operatorname{Pr}>f=0.000)$ have the significant difference value while for SRFC tests, 20 meter Sprint test $(\operatorname{Pr}>f=0.000)$, Vertical Jump test $(\operatorname{Pr}>f=0.000)$, Standing Broad Jump test $(\operatorname{Pr}>f=0.000)$, and $T$ test $(\operatorname{Pr}>f=0.011)$ have the significant difference for this study.

As for HRFC tests, in Sit and Reach test, team sport athlete with underweight BMI performs better than the rest of the type of sport and BMI class. As for Push Up test, can be see that individual sport athlete with normal BMI class have the greatest performance in this test than the rest. Individual sport athlete with overweight performs better than the rest in handgrip test. As for Predicted VO2max, individual sports athlete resulting a better performance in this test than others. For Standing Medicine Ball Throw, team sport athlete with overweight BMI have the greatest performance than others. Figure 1, 2, 3, 4 and 5 shows the graph for the MANOVA analysis result for significant difference test in HRFC.

For SRFC tests, team sport athlete with underweight BMI dominating the 20 meter Sprint test and Standing Broad Jump test than other all BMI class for each type of sports athlete. For Vertical Jump test, individual sport athlete with normal BMI class performs better than any BMI class from each type of sport athlete. For final significant test $T$ test, founded that team sports with overweight BMI class was better than all type of sport including their BMI class. Figure 6, 7, 8, and 9 shows the graph for the MANOVA analysis result for significant difference test in SRFC. 
INTERNATIONAL JOURNAL OF ACADEMIC RESEARCH IN PROGRESSIVE EDUCATION AND DEVELOPMENT

Vol. 11, No. 1, 2022, E-ISSN: 2226-6348 @ 2022 HRMARS

Table 1: MANOVA result for Health Related Fitness Component

\begin{tabular}{lrrrrrr}
\hline & SIT AND & SIT & PUSH & HAND & VO2M & MEDICINE BALL \\
& REACH & UP & \multicolumn{1}{c}{ UP } & GRIP & AX & THROW \\
\hline INDIVIDUAL & & 39.90 & 61.06 & 40.937 & 41.83 & \\
SPORTS*NORMAL & $39.808 \mathrm{~b}$ & $0 \mathrm{a}$ & $7 \mathrm{~b}$ & $\mathrm{~b}$ & $3 \mathrm{~b}$ & $5.816 \mathrm{ab}$ \\
TEAM & & 42.22 & 41.11 & 43.789 & 46.17 & \\
SPORTS*NORMAL & $38.811 \mathrm{~b}$ & $9 \mathrm{a}$ & $4 \mathrm{a}$ & $\mathrm{b}$ & $1 \mathrm{~b}$ & $6.931 \mathrm{bc}$ \\
INDIVIDUAL & & 35.57 & 43.00 & 47.686 & 34.35 & \\
SPORTS*OVERWEIGHT & $35.693 \mathrm{ab}$ & $1 \mathrm{a}$ & $0 \mathrm{ab}$ & $\mathrm{b}$ & $7 \mathrm{a}$ & $7.209 \mathrm{bc}$ \\
TEAM & & 41.81 & 31.13 & 47.373 & 43.59 & \\
SPORTS*OVERWEIGHT & $39.345 \mathrm{~b}$ & $8 \mathrm{a}$ & $6 \mathrm{a}$ & $\mathrm{b}$ & $1 \mathrm{~b}$ & $7.642 \mathrm{c}$ \\
TEAM & & & & & & \\
SPORTS*UNDERWEIGH & & 35.33 & 54.00 & 44.067 & 41.66 & \\
T & $40.500 \mathrm{~b}$ & $3 \mathrm{a}$ & $0 \mathrm{ab}$ & $\mathrm{b}$ & $7 \mathrm{ab}$ & $6.643 \mathrm{bc}$ \\
INDIVIDUAL & & & & & & \\
SPORTS*UNDERWEIGH & & 39.84 & 23.38 & 29.200 & 46.61 & \\
T & $30.400 \mathrm{a}$ & $6 \mathrm{a}$ & $5 \mathrm{a}$ & $\mathrm{a}$ & $5 \mathrm{~b}$ & $4.576 \mathrm{a}$ \\
\hline Pr>F & 0.000 & 0.419 & 0.000 & 0.000 & 0.000 & 0.000
\end{tabular}

Table 2: MANOVA result for Skill Related Fitness Component

\begin{tabular}{|c|c|c|c|c|c|}
\hline & $\begin{array}{l}20 \text { METER } \\
\text { SPRINT }\end{array}$ & $\begin{array}{l}\text { VERTICAL } \\
\text { JUMP }\end{array}$ & $\begin{array}{l}\text { STANDING } \\
\text { BROAD JUMP }\end{array}$ & $\begin{array}{l}\text { STORK } \\
\text { STAND } \\
\end{array}$ & T TEST \\
\hline INDIVIDUAL & & & & & 11.47 \\
\hline SPORTS*NORMAL & $3.396 a b c$ & $45.842 \mathrm{c}$ & $215.875 a b$ & $31.116 \mathrm{a}$ & $\begin{array}{r}0 \mathrm{ab} \\
11.26\end{array}$ \\
\hline $\begin{array}{l}\text { TEAM SPORTS*NORMAL } \\
\text { INDIVIDUAL }\end{array}$ & $3.149 a b$ & $33.880 a b$ & $233.886 a b$ & $37.926 \mathrm{a}$ & $\begin{array}{r}7 \mathrm{ab} \\
12.11\end{array}$ \\
\hline $\begin{array}{l}\text { SPORTS*OVERWEIGHT } \\
\text { TEAM }\end{array}$ & $3.546 \mathrm{bc}$ & $43.679 \mathrm{c}$ & $202.500 \mathrm{a}$ & $17.845 \mathrm{a}$ & $\begin{array}{r}4 b \\
10.99\end{array}$ \\
\hline $\begin{array}{l}\text { SPORTS*OVERWEIGHT } \\
\text { TEAM }\end{array}$ & $3.210 \mathrm{ab}$ & $\begin{array}{r}31.114 \mathrm{a} \\
41.667\end{array}$ & $232.136 \mathrm{ab}$ & $17.621 \mathrm{a}$ & $\begin{array}{r}0 \mathrm{ab} \\
10.40\end{array}$ \\
\hline $\begin{array}{l}\text { SPORTS*UNDERWEIGHT } \\
\text { INDIVIDUAL }\end{array}$ & $3.100 \mathrm{a}$ & $a b c$ & $246.333 b$ & $18.923 \mathrm{a}$ & $\begin{array}{r}7 \mathrm{a} \\
11.71\end{array}$ \\
\hline SPORTS*UNDERWEIGHT & $3.715 c$ & $43.115 \mathrm{bc}$ & $195.538 \mathrm{a}$ & $45.170 \mathrm{a}$ & $2 b$ \\
\hline $\operatorname{Pr}>\mathrm{F}$ & 0.000 & 0.000 & 0.000 & 0.101 & 0.011 \\
\hline
\end{tabular}


INTERNATIONAL JOURNAL OF ACADEMIC RESEARCH IN PROGRESSIVE EDUCATION AND DEVELOPMENT

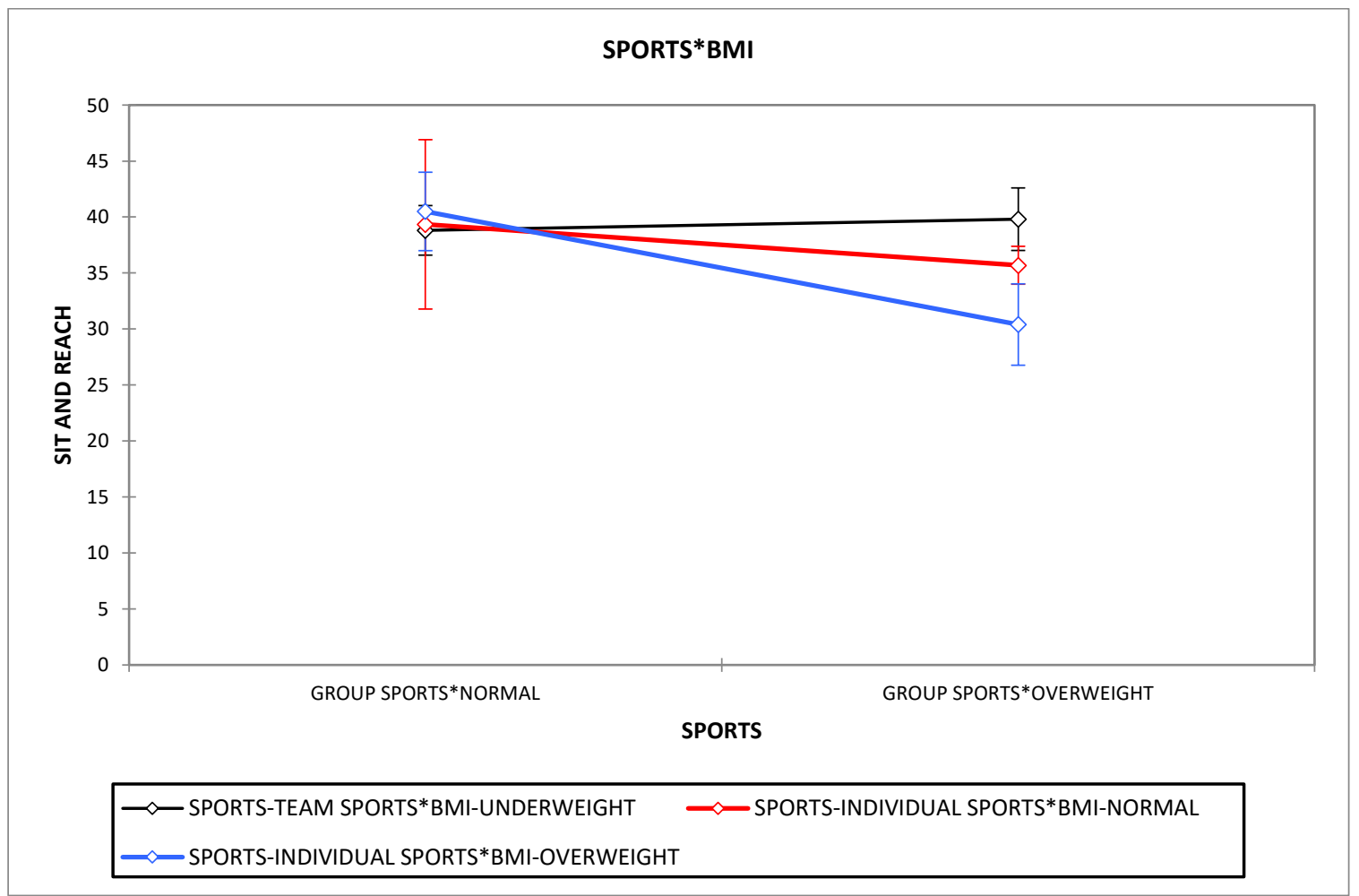

Figure 1: Sit and Reach MANOVA result

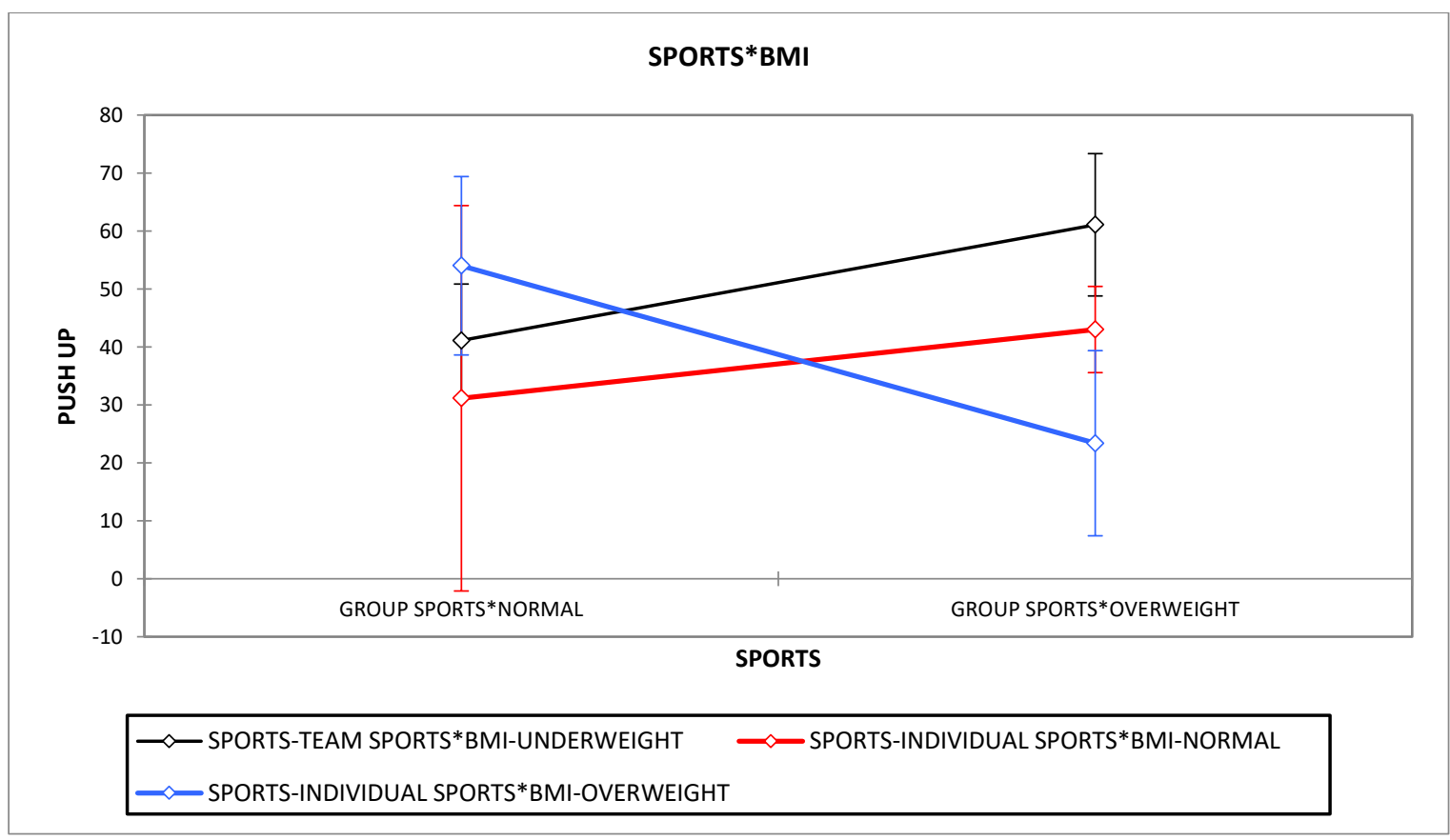

Figure 2: Push up test MANOVA result 
INTERNATIONAL JOURNAL OF ACADEMIC RESEARCH IN PROGRESSIVE EDUCATION AND DEVELOPMENT

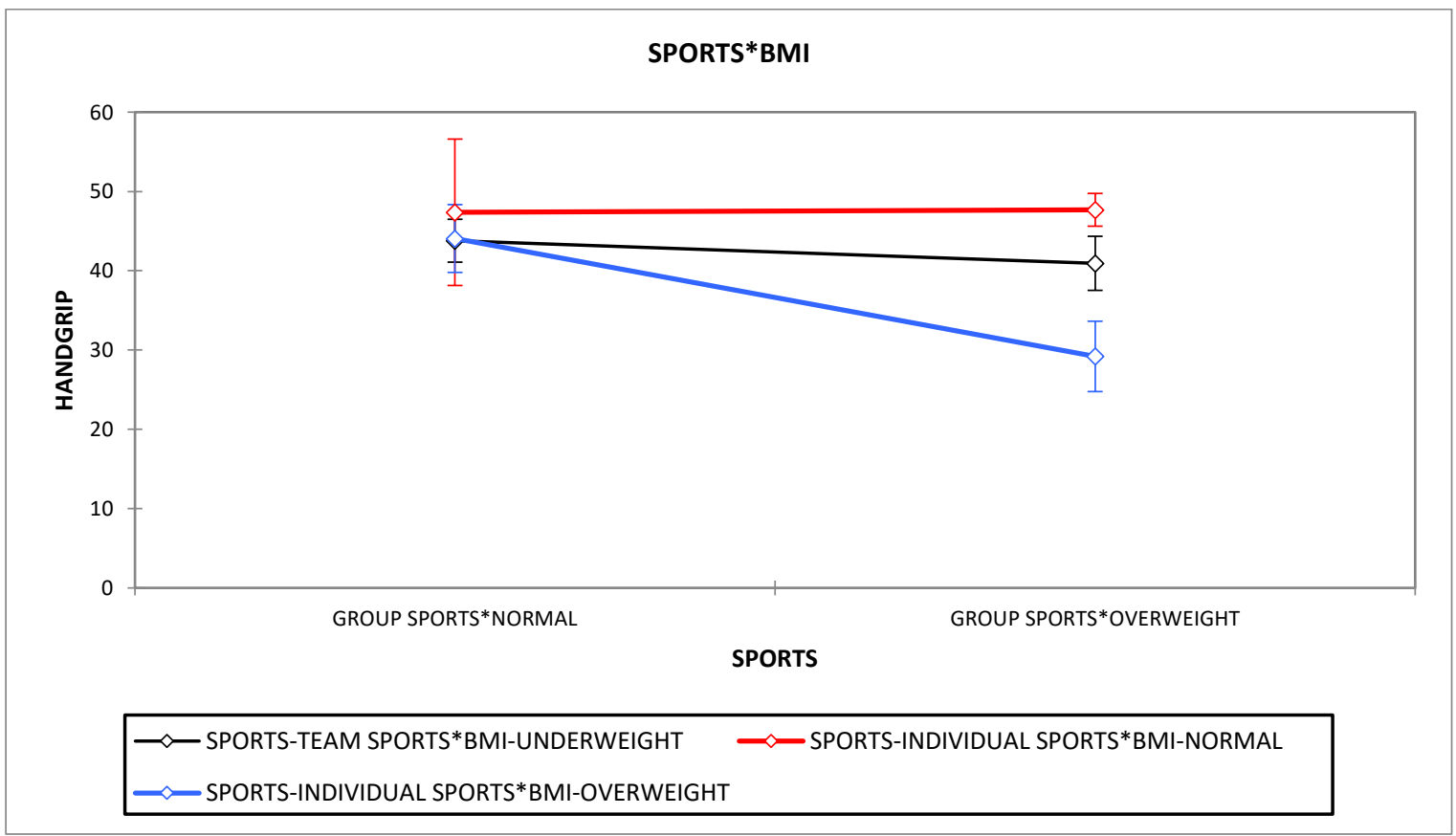

Figure 3: Handgrip test MANOVA result

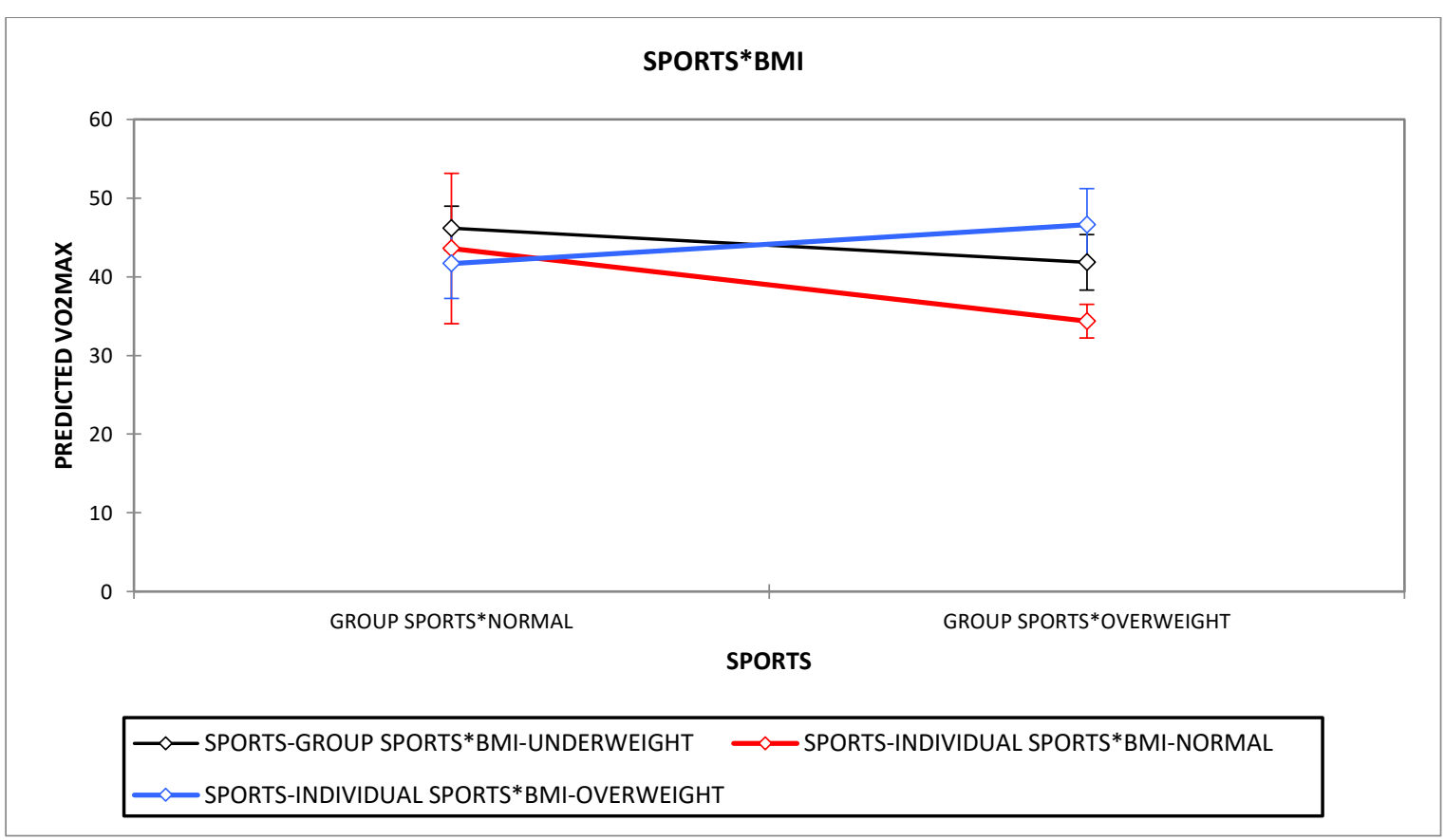

Figure 4: Predicted VO2max test MANOVA result 
INTERNATIONAL JOURNAL OF ACADEMIC RESEARCH IN PROGRESSIVE EDUCATION AND DEVELOPMENT

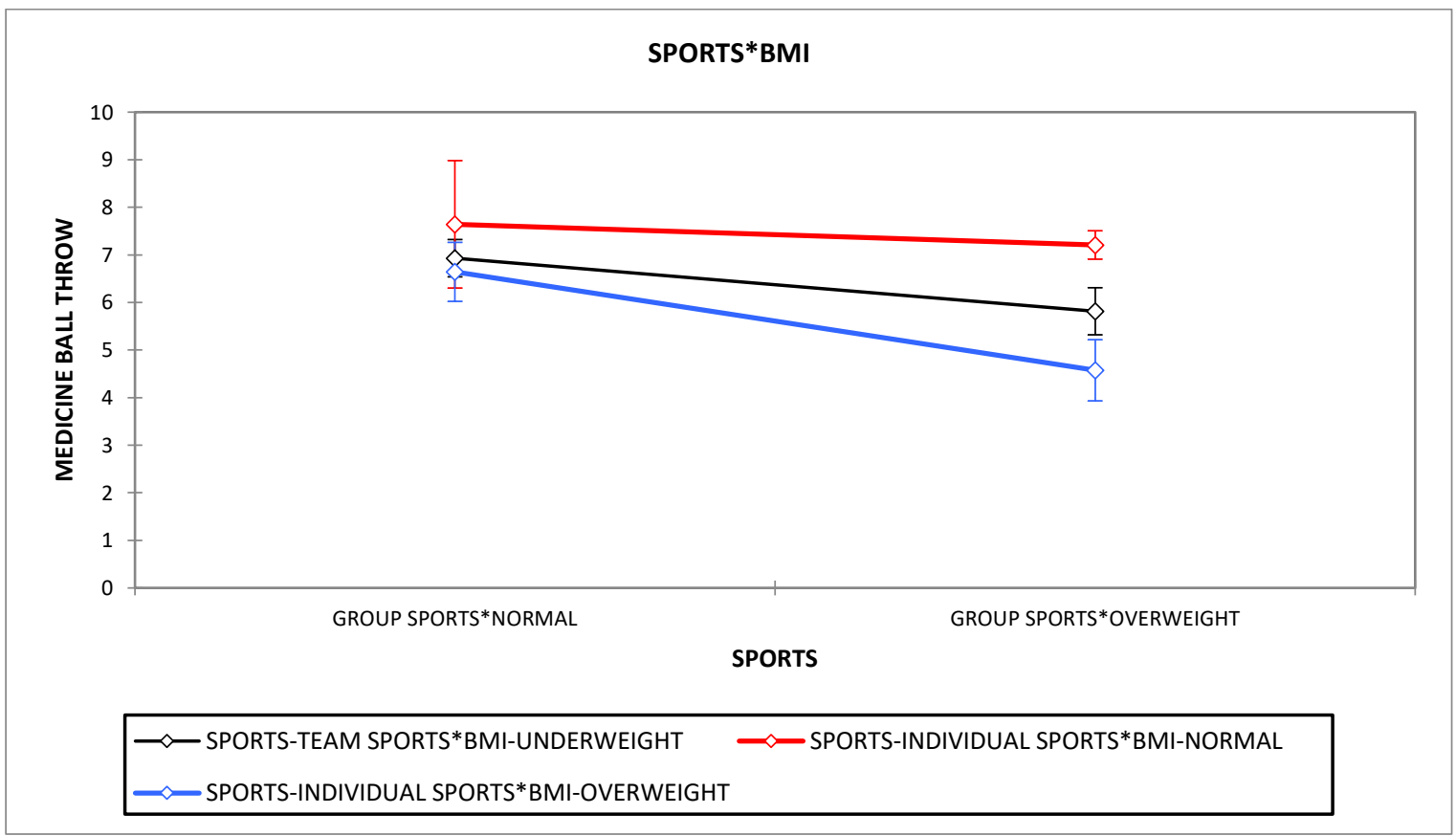

Figure 5: Medicine Ball Throw test MANOVA result

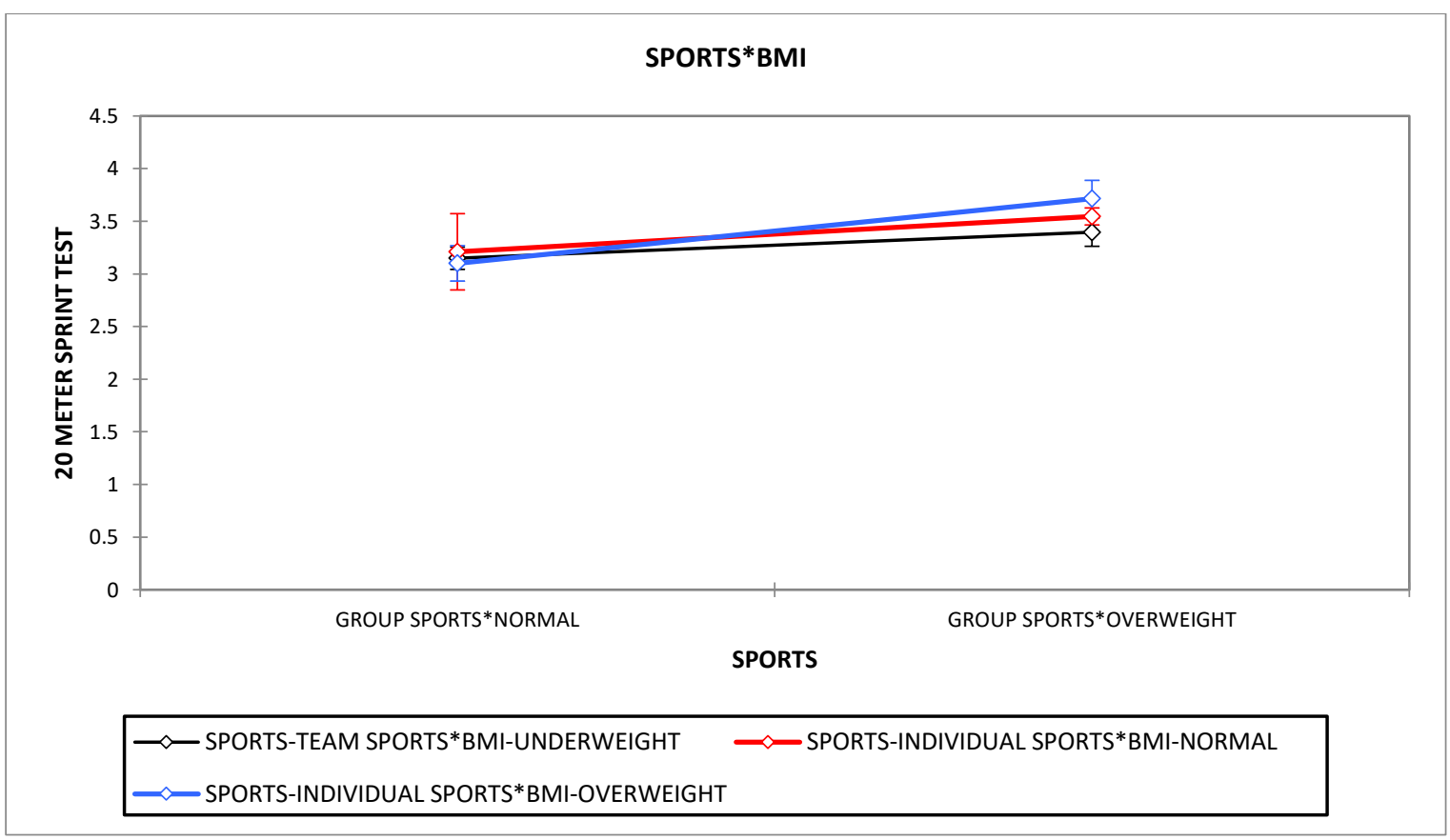

Figure 6: 20 meter Sprint test MANOVA result 
INTERNATIONAL JOURNAL OF ACADEMIC RESEARCH IN PROGRESSIVE EDUCATION AND DEVELOPMENT

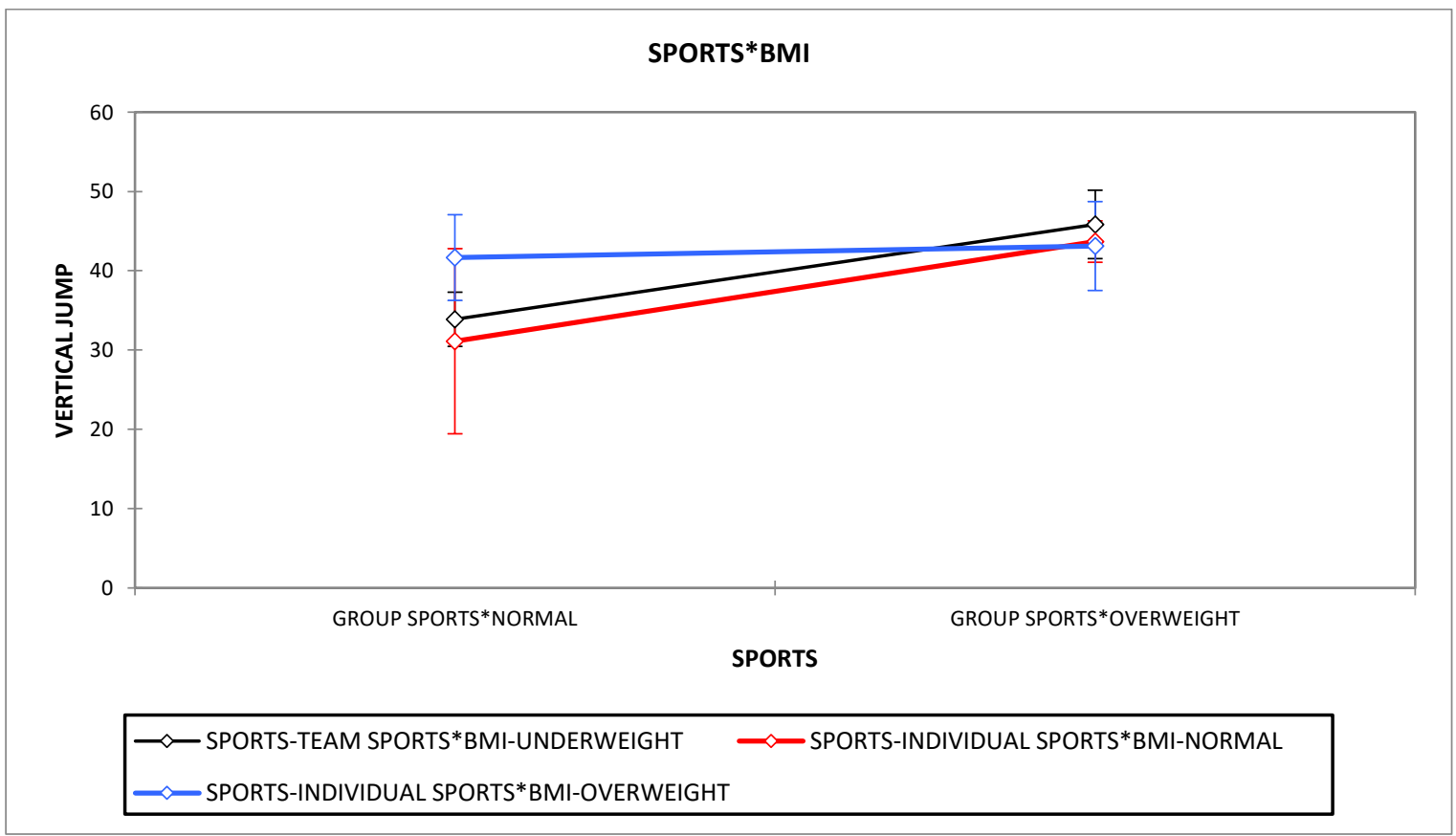

Figure 7: Vertical Jump test MANOVA result

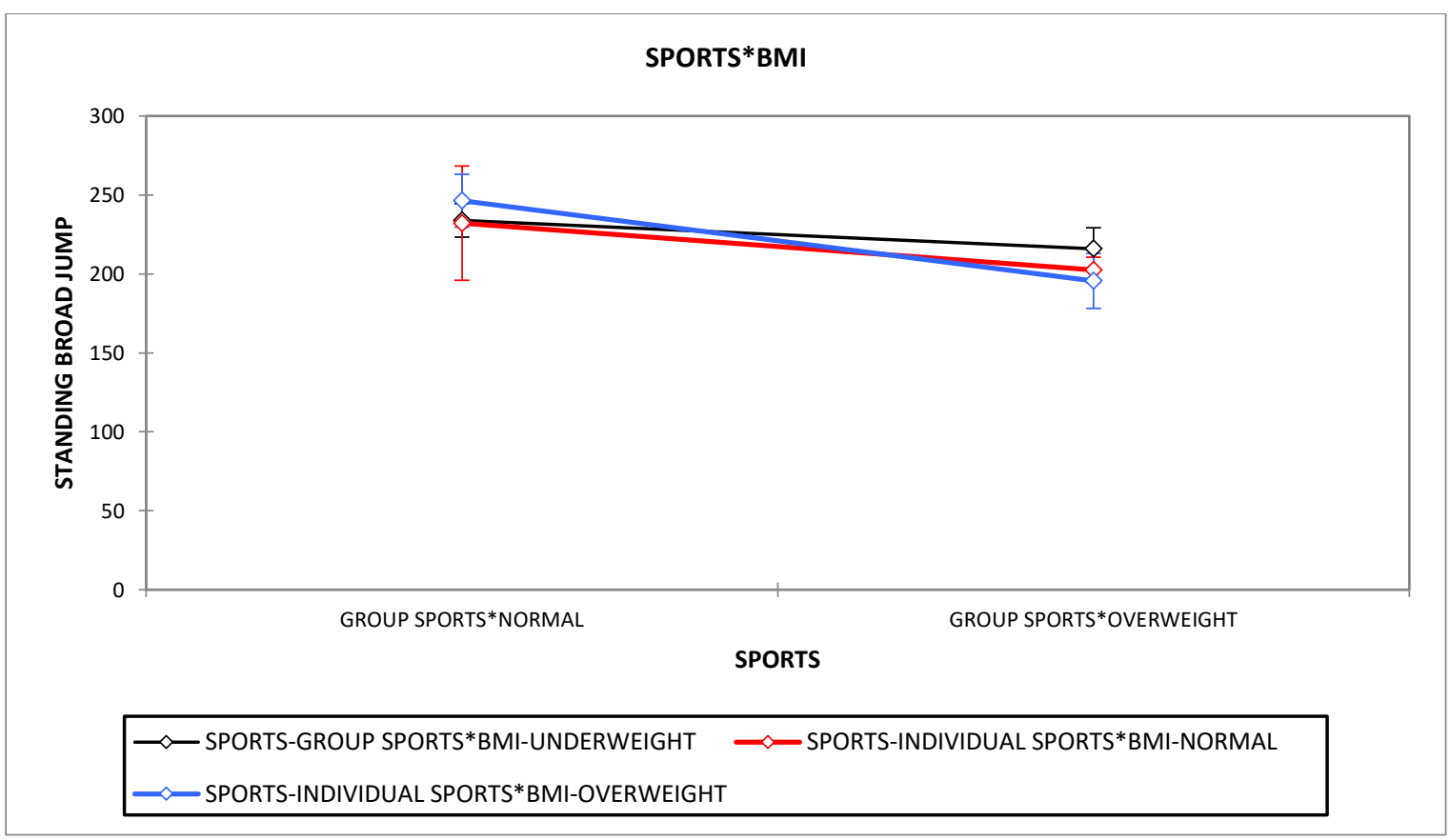

Figure 8: Standing Broad Jump test MANOVA result 


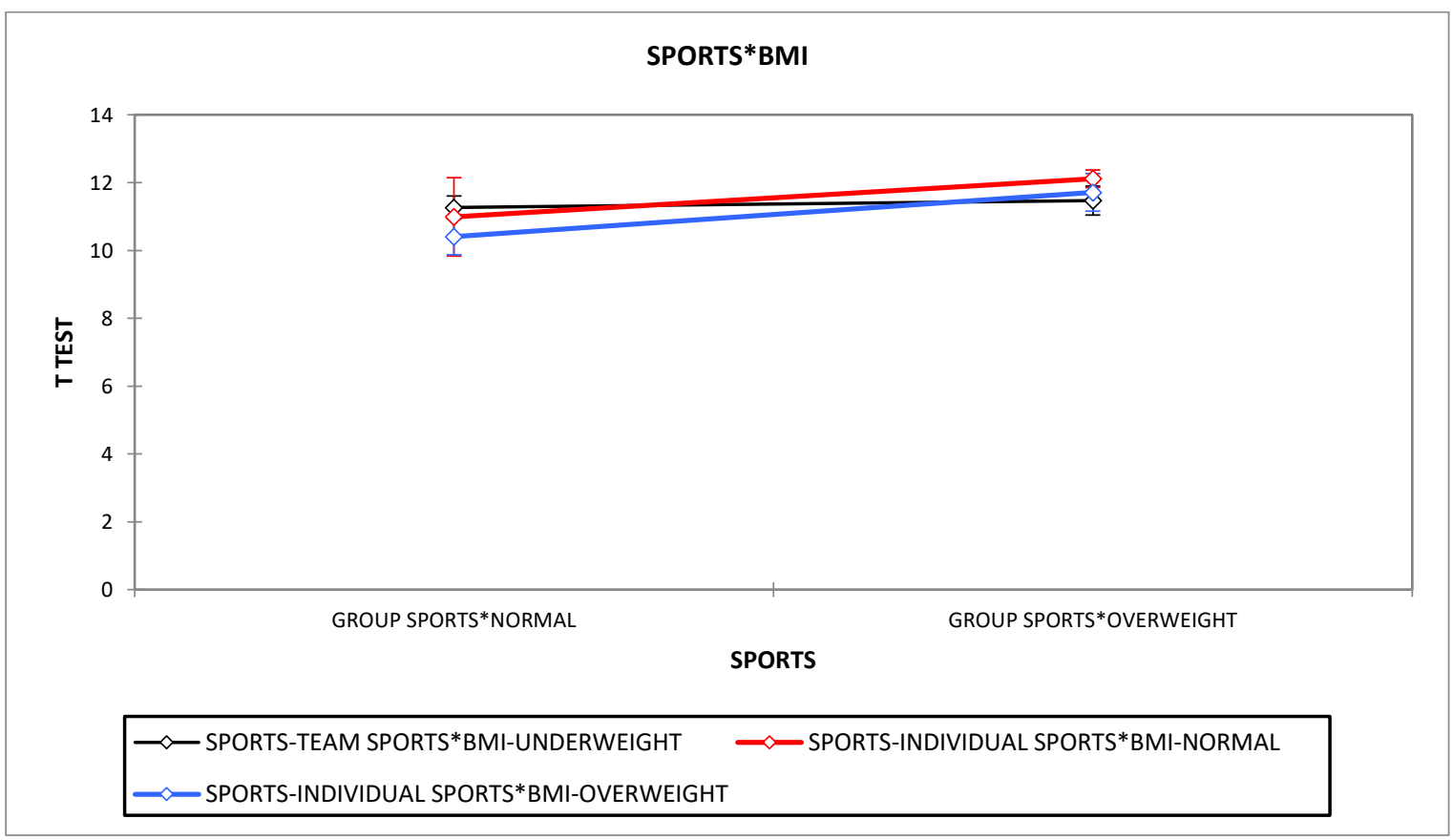

Figure 9: T test MANOVA result

\section{Discussion}

The purpose of this study is to differentiate the fitness performance based on BMI of individual sport and team sport athletes. From the findings above, it shows that individual sport athletes are dominating in term of excellency for the HRFC (upper muscular strength, grip strength, and cardiovascular) while team sport athletes excels in SRFC (speed, agility, and leg explosive power). In HRFC analysis result, founded also team sport athletes with normal BMI did not contribute to any excellent performance in the HRFC tests. Also, in SRFC analysis result, both overweight $\mathrm{BMI}$ individual and team sports, individual sports athlete with underweight BMI resulting a poor performance in SRFC tests.

However, team sport athletes with underweight BMI showing a great performance in both HRFC and SRFC while dominating in the sit and reach test (flexibility), 20 meter sprint test (speed), and T test (agility). This finding is supported by the previous study reported that A team sport athlete who was underweight performed admirably in the speed and agility component (Ibrahim et al., 2021; Rinaldo et al., 2020). In previous study stating the In comparison to overweight and obese team sport athletes, underweight and normal weight team sports scored higher on the flexibility test (Bittencourt et al., 2017; Ponce-González et al., 2020). From a previous study, can be simplified that team sport underweight athletes are suits to put in the position that require great performance of speed, agility and flexibility such as goalkeeper and forward in football and hockey as generally know these position speed and agility also these positions are require to play in many matches, so Flexibility is required here to avoid injuries, as flexibility has been shown to help minimise injuries (Cejudo et al., 2019; Witvrouw et al., 2003). Team sport overweight athlete founded is good in upper body strength. Mclntyre (2005) stating Athletes in team sports with low body fat levels have more muscular strength than athletes with high body fat levels. This literature is contradict with this study findings, this is the potential rise and influence intramuscular fat has on muscle mechanics, as a result of increasing age and obesity, is produced by diminishing muscle quality. (Rahemi et al., 2015; Tomlinson et al., 2016). Team sport normal BMI athletes showed 
a good performance in leg explosive power. This is a newly founded result although athlete with normal BMI supposed to have a great performance in leg explosive power but these findings need a literature and another specific study to support this study.

Individual sport athletes with normal BMI class founded in this analysis result to be good at upper muscular strength and leg power. Abidin \& Adam, (2013) also conclude the same findings as this study stating that lower BMI class individual sport athlete have a great upper muscle strength and leg power. Individual sport athlete with overweight BMI class analysed to be good in handgrip strength, this study on handgrip test result were contradict with Lopes et al., (2019) stating higher class of BMI do have great ability in grip strength. Individual sport athlete with underweight BMI class founded was good in cardiovascular. The reason behind this is that there is an increase in Type II muscle fibres and a decrease in Type I muscle fibres in obese people, which might lead to lower oxygen absorption. Reduced maximum oxygen intake is another effect of increased BMI (Kalyanshetti \& Veluru, 2017; Vijaykumar et al., 2021)

From the all the finding's result, can be simplified that overweight athlete in every type of sport showing poor performance proved by in this study analysis stating overweight athlete from both type of sports dominates only one fitness component from HRFC and none in SRFC. These findings supported the theory from Wilborn et al., (2005) stating etiology of increased body fat is multi-factorial and is evident in the abnormal levels of many biological molecules such as genetic, physiological, and behavioural factors.

\section{Conclusion}

From the discussion above, it can be concluded that some of the test shown their significant differences and from the significant differences between the test, showed that all representative athletes with their respective BMI have differences in physical fitness performance as in this study has shown that individual sports athletes with underweight, normal, and overweight BMI classes showed excellent performance in HRFC test while team sports with underweight and BMI normally dominates individual sports in the SRFC test. From this result, practitioners can maintain their BMI to stay on track in order to avoid restriction on their performance also to avoid bias and discrimination in performance monitoring and selection during pre-match and in match. From the avoidance of performance's restriction and discrimination in performance monitoring, practitioners can increase their performance to a higher level without hindrance in terms of anthropometry. With this also the number of elite athletes will also increase and therefore the selection of athletes to be placed in the formation and applied into a tactical for coaches will be easier by armed with high quality athletes without the perception of unfair selection. More studies are needed to understand the complexity of this topic especially focusing on the recognize the specificity requirement of physical fitness on different type of sport and BMI class.

\section{References}

Abd Hadi, N. H., Abdullah, M. R., Juahir, H., Rahim, A. I., Elumalai, G., Nadzmi, A., \& Maliki, A. B. H. M. (2021). Physical Fitness Key Parameter for Sport Schools Young Athletes in Malaysia. International Journal of Academic Research in Progressive Education and Development, 10(2). https://doi.org/10.6007/IJARPED/V10-12/8799

Abdullah, M. R., Bisyri, A., Maliki, H. M., Musa, R. M., Kosni, N. A., Juahir, H., \& Haque, M. 
(2016). Multi-Hierarchical Pattern Recognition of Athlete's Relative Performance as A Criterion for Predicting Potential Athletes. Journal of Young Pharmacists, 8(4), 463-470. https://doi.org/10.5530/jyp.2016.4.24

Abdullah, M. R., Nidzam, M. S., Hairi, A., Musa, R. M., Bisyri, A., Maliki, H. M., \& Kosni, N. A. (2017). PREDICTION OF SPECIFIC PHYSICAL CHARACTERISTIC AND FITNESS RELATED VARIABLES ON CARDIOVASCULAR ENDURANCE AMONG SOME SELECTED MALE UNIFORM ARM UNITS OF UNIVERSITI SULTAN ZAINAL ABIDIN, MALAYSIA. In Health \& Exercise (Vol. 6, Issue 1).

Abidin, N. Z., \& Adam, M. B. (2013). Prediction of Vertical Jump Height from Anthropometric Factors in Male and Female Martial Arts Athletes. The Malaysian Journal of Medical Sciences : MJMS, 20(1), 39. /pmc/articles/PMC3684376/

Ackland, T. R., Lohman, T. G., Sundgot-Borgen, J., Maughan, R. J., Meyer, N. L., Stewart, A. D., \& Mller, W. (2012). Current Status of Body Composition Assessment in Sport. Sports Medicine 2012 42:3, 42(3), 227-249. https://doi.org/10.2165/11597140-00000000000000

Bacciotti, S., Baxter-Jones, A., Gaya, A., \& Maia, J. (2017). The Physique of Elite Female Artistic Gymnasts: A Systematic Review. Journal of Human Kinetics, 58(1), 247-259. https://doi.org/10.1515/HUKIN-2017-0075

Bisyri, A., Maliki, H. M., Abdullah, M. R., Juahir, H., Abdullah, F., Ain, N., Abdullah, S., Musa, R. M., Musliha Mat-Rasid, S., Adnan, A., Azura Kosni, N., Amalina, W. S., Muhamad, W., Afiqah, N., \& Nasir, M. (2017). A multilateral modelling of Youth Soccer Performance Index (YSPI) Related content The role of anthropometric, growth and maturity index (AGaMI) influencing youth soccer relative performance A multilateral modelling of Youth Soccer Performance Index (YSPI). https://doi.org/10.1088/1757899X/342/1/012057

Bittencourt, A. dos S., Vieira, P. A. S., Ferreira, M. C. C., Primo, L. L., Deiró, T. N., Avelino, P. R., Menezes, K. K. P. de, Lage, S. M., \& Costa, H. S. (2017). The Impact of Overweight on Flexibility and Functional Capacity. Journal of Novel Physiotherapies, 7(6), 1-5. https://doi.org/10.4172/2165-7025.1000368

Campa, F., Toselli, S., Mazzilli, M., Alberto Gobbo, L., \& Coratella, G. (2021). Assessment of Body Composition in Athletes: A Narrative Review of Available Methods with Special Reference to Quantitative and Qualitative Bioimpedance Analysis. https://doi.org/10.3390/nu13051620

Cejudo, A., Robles-Palazón, F. J., Ayala, F., De Ste Croix, M., Ortega-Toro, E., SantonjaMedina, F., \& De Baranda, P. S. (2019). Age-related differences in flexibility in soccer players 8-19 years old. PeerJ, 2019(1), e6236. https://doi.org/10.7717/PEERJ.6236/SUPP-1

Chandra, A., Pant, B., Chandra, A., Rajbhandari, R., Gajuryal, S., Shrestha, P., Acharya, S., Rajbhandari, P., Rajbhandari, P., \& Prakash, P. (2020). Status of serum vitamin D and neurological disorder in Nepalese population: a prospective study. Life Research, 3(4), 148. https://doi.org/10.53388/LIFE2020-1002-103

Faizatul, N., Binti Jibril, A., Abdullah, M. R., Bisyri, A., Maliki, H. M., Puspitasari, I. M., Nawi, N. A., Nadzmi, A., Amirur, M., Zainoddin, R., \& Yuningsih, S. H. (2021). Comparison of Body Mass Index Class Against Motor Performance Towards 7-Year-Old Boys in Malaysia. Proceedings of the First International Conference on Science, Technology, Engineering and Industrial Revolution (ICSTEIR 2020), 536, 561-566.

https://doi.org/10.2991/ASSEHR.K.210312.090 
Franchini, E., Brito, C. J., \& Artioli, G. G. (2012). Weight loss in combat sports: Physiological, psychological and performance effects. Journal of the International Society of Sports Nutrition, 9(1), 1-6. https://doi.org/10.1186/1550-2783-9-52/TABLES/1

Gipit Charles, M. A., Abdullah, M. R., Musa, R. M., Kosni, N. A., \& Maliki, A. B. H. M. (2017). The effectiveness of traditional games intervention program in the improvement of form one school-age children's motor skills related performance components. Journal of Physical Education and Sport, 17, 925-930. https://doi.org/10.7752/JPES.2017.S3141

Hardy, R., Cooper, R., Aihie Sayer, A., Ben-Shlomo, Y., Cooper, C., Deary, I. J., Demakakos, P., Gallacher, J., Martin, R. M., McNeill, G., Starr, J. M., Steptoe, A., Syddall, H., \& Kuh, D. (2013). Body Mass Index, Muscle Strength and Physical Performance in Older Adults from Eight Cohort Studies: The HALCyon Programme. PLOS ONE, 8(2), e56483. https://doi.org/10.1371/JOURNAL.PONE.0056483

Ibrahim, S., Kumar, R., \& Ahmed, S. A. (2021). Influence of 6-Week Pooled Soccer Plyometric and Sprint Training on Speed and Agility amongst Underweight. Entomology and Applied Science Letters, 8(1), 28-34. https://doi.org/10.51847/UP6ZRV6QJO

Kalyanshetti, S. B., \& Veluru, S. (2017). A cross-sectional study of association of body mass index and VO 2 max by nonexercise test in medical students. National Journal of Physiology, Pharmacy and Pharmacology, 228(2).

https://doi.org/10.5455/njppp.2017.7.0825804092016

Lopes, V. P., Malina, R. M., Gomez-Campos, R., Cossio-Bolaños, M., de Arruda, M., \& Hobold, E. (2019). Body mass index and physical fitness in Brazilian adolescents. Jornal de Pediatria, 95(3), 358-365. https://doi.org/10.1016/J.JPED.2018.04.003

Lozovina, M., Lozovina, V., \& Pavičić, L. (2012). Morphological changes in elite male water polo players. Acta Kinesiologica, 6, 85-90.

Lozovina, V., \& Lozovina, M. (2008). MORPHOLOGICAL OPTIMISATION, OVERLAP ZONES AND SECULAR TREND IN SELECTION PRESSURES. Acta Kinesiologica, 2, 35-41.

McIntyre, M. C. (2005). A comparison of the physiological profiles of elite Gaelic footballers, hurlers, and soccer players. British Journal of Sports Medicine, 39(7), 437-439. https://doi.org/10.1136/BJSM.2004.013631

Mujika, I., Halson, S., Burke, L. M., Balagué, G., \& Farrow, D. (2018). An Integrated, Multifactorial Approach to Periodization for Optimal Performance in Individual and Team Sports. International Journal of Sports Physiology and Performance, 13(5), 538561. https://doi.org/10.1123/IJSPP.2018-0093

Nadzmi, A., Abdullah, M. R., Maliki, A. B. H. M., Renaldi, F., \& Sukono. (2021). Comparison Between Gross Motor Skills Performance and 7-Years-Old Children with Controlled Effect of Residential Area. Proceedings of the First International Conference on Science, Technology, Engineering and Industrial Revolution (ICSTEIR 2020), 536. https://doi.org/10.2991/ASSEHR.K.210312.007

Nikolaidis, T, P., \& Ingebrigtsen, J. (2013). The relationship between body mass index and physical fitness in adolescent and adult male team handball players. Article in Indian Journal of Physiology and Pharmacology, 57(4), 361-371. https://www.researchgate.net/publication/259145245

Nikolaidis, P. T., Chtourou, H., Torres-Luque, G., Rosemann, T., \& Knechtle, B. (2019). The Relationship of Age and BMI with Physical Fitness in Futsal Players. https://doi.org/10.3390/sports7040087

Owen, A. L., Lago-Peñas, C., Dunlop, G., Mehdi, R., Chtara, M., \& Dellal, A. (2018). Seasonal Body Composition Variation Amongst Elite European Professional Soccer Players: An 
Approach of Talent Identification. Journal of Human Kinetics, 62(1), 177. https://doi.org/10.1515/HUKIN-2017-0132

Ponce-González, J. G., Gutiérrez-Manzanedo, J. V., De Castro-Maqueda, G., FernándezTorres, V. J., \& Fernández-Santos, J. R. (2020). The Federated Practice of Soccer Influences Hamstring Flexibility in Healthy Adolescents: Role of Age and Weight Status. Sports 2020, Vol. 8, Page 49, 8(4), 49. https://doi.org/10.3390/SPORTS8040049

Rahemi, H., Nigam, N., \& Wakeling, J. M. (2015). The effect of intramuscular fat on skeletal muscle mechanics: implications for the elderly and obese. Journal of The Royal Society Interface, 12(109). https://doi.org/10.1098/RSIF.2015.0365

Rinaldo, N., Toselli, S., Gualdi-Russo, E., Zedda, N., \& Zaccagni, L. (2020). Effects of Anthropometric Growth and Basketball Experience on Physical Performance in PreAdolescent Male Players. International Journal of Environmental Research and Public Health 2020, Vol. 17, Page 2196, 17(7), 2196. https://doi.org/10.3390/IJERPH17072196

Roelofs, E. J., Smith-Ryan, A. E., Trexler, E. T., \& Hirsch, K. R. (2017). Seasonal Effects on Body Composition, Muscle Characteristics, and Performance of Collegiate Swimmers and Divers. Journal of Athletic Training, 52(1), 45-50. https://doi.org/10.4085/1062-605051.12.26

Ryan, E. D., Everett, K. L., Smith, D. B., Pollner, C., Thompson, B. J., Sobolewski, E. J., \& Fiddler, R. E. (2014). Acute effects of different volumes of dynamic stretching on vertical jump performance, flexibility and muscular endurance. Clinical Physiology and Functional Imaging, 34(6), 485-492. https://doi.org/10.1111/cpf.12122

Rydzik, Ł., \& Ambroży, T. (2021). Physical fitness and the level of technical and tactical training of kickboxers. International Journal of Environmental Research and Public Health, 18(6), 1-9. https://doi.org/10.3390/IJERPH18063088

Schorderet, C., Hilfiker, R., \& Allet, L. (2021). The role of the dominant leg while assessing balance performance. A systematic review and meta-analysis. Gait \& Posture, 84, 6678. https://doi.org/10.1016/J.GAITPOST.2020.11.008

Stockbrugger, B. A., \& Haennel, R. G. (2001). Validity and Reliability of a Medicine Ball Explosive Power Test. Journal of Strength and Conditioning Research, 15(4), 431-438. https://doi.org/10.1519/1533-4287(2001)015<0431:VAROAM>2.0.CO;2

Suhaimi, M. Z., Musa, R. M., Suhaimi, M. Z., Abdullah, M. R., Husin, A. B., \& Maliki, M. (2021). The Effect of Body Mass Index on Health-Related Parameters in University Students. Research J. Pharm. and Tech, 14(6). https://doi.org/10.52711/0974360X.2021.00569

Sundgot-Borgen, J., \& Torstveit, M. K. (2010). Aspects of disordered eating continuum in elite high-intensity sports. Scandinavian Journal of Medicine \& Science in Sports, 20(SUPPL. 2), 112-121. https://doi.org/10.1111/J.1600-0838.2010.01190.X

Taha, Z., Musa, R. M., P.P. Abdul Majeed, A., Alim, M. M., \& Abdullah, M. R. (2018). The identification of high potential archers based on fitness and motor ability variables: $A$ Support Vector Machine approach. Human Movement Science, 57, 184-193. https://doi.org/10.1016/J.HUMOV.2017.12.008

Tomlinson, D. J., Erskine, R. M., Morse, C. I., Winwood, K., \& Onambélé-Pearson, G. (2016). The impact of obesity on skeletal muscle strength and structure through adolescence to old age. Biogerontology, 17(3), 467. https://doi.org/10.1007/S10522-015-9626-4

Vijaykumar, N., Jadhav, S., \& Badiger, S. (2021). Influence of body fat, lean body mass, and body mass index levels on maximal oxygen consumption using submaximal exercise in young adults: An observational study. National Journal of Physiology, Pharmacy and 
Pharmacology, 11, 7. https://doi.org/10.5455/njppp.2021.11.01042202108022021 Wilborn, C., Beckham, J., Campbell, B., Harvey, T., Galbreath, M., Bounty, P. La, Nassar, E., Wismann, J., \& Kreider, R. (2005). Obesity: Prevalence, Theories, Medical Consequences, Management, and Research Directions. Journal of the International Society of Sports Nutrition, 2(2), 4. https://doi.org/10.1186/1550-2783-2-2-4

Witvrouw, E., Danneels, L., Asselman, P., D’Have, T., \& Cambier, D. (2003). Muscle flexibility as a risk factor for developing muscle injuries in male professional soccer players: $A$ prospective study. American Journal of Sports Medicine, 31(1), 41-46.

https://doi.org/10.1177/03635465030310011801

Zientek, L. R., \& Thompson, B. (2009). Matrix summaries improve research reports:

Secondary analyses using published literature. Educational Researcher, 38(5), 343-352. https://doi.org/10.3102/0013189X09339056 